\title{
A válságok hatása a politikai rendszerekre
}

\author{
Stumpf István \\ Széchenyi István Egyetem Deák Ferenc Állam- és Jogtudományi Kar \\ Alkotmányjogi és Politikatudományi Tanszék, Győr, Magyarország \\ Nemzeti Közszolgálati Egyetem Eötvös József Kutatóközpont Amerika Tanulmányok Kutatóintézet, \\ Budapest, Magyarország \\ Beérkezett: 2021. július 14.; Elfogadva: 2021. augusztus 5.
}

\begin{abstract}
Összefoglalás
A második világháborút követően talán nem volt egyetlen esemény sem, amely olyan hatást gyakorolt a világ országaira, mint a koronavírus-járvány kirobbanása. A vírus-válság felgyorsította a liberális világrend erózióját, kiélezte a nagyhatalmak közötti ellentéteket, válságforgatókönyvek és prognózisok készültek. A válság rávilágított arra is, hogy kudarcra vannak ítélve azok a kormányzatok, amelyek nem ruháztak be a közösségi infrastruktúrába, és elhanyagolták a közszolgálati tudást. Az is kiderült, hogy a kormányzati intézményeknek szakértőkre és nem lojális mamelukokra van szüksége a válsághelyzetből fakadó közpolitikai gondok megoldása során. Egy világméretú és példátlan sebességgel terjedő válság elleni eredményes fellépés elsődleges frontvonala tehát a nemzetállam maradt.
\end{abstract}

Kulcsszavak: koronavírus-járvány, válság, nemzetállam, kormányzat, alkotmányosság

\section{The impact of crisis on political systems}

\author{
István Stumpf
}

Széchenyi István University, Deák Ferenc Faculty of Law and Political Sciences,

Department of Constitutional Law and Political Science, Győr, Hungary

University of Public Service, Eötvös József Research Center, American Studies Research Institute, Budapest, Hungary

\section{Summary}

In times of crisis, all political systems give the executive exceptional powers, as it is not possible to face new and rapidly changing challenges within the framework of existing laws. One of the American founding fathers, Alexander Hamilton, who feared the excessive power of central government, believed that in times of emergency the system of checks and balances should be suspended. Constitutional democracy will be threatened if the rule of law is not restored after the emergency has passed.

Perhaps no event since the Second World War has had such an impact on the countries of the world as the outbreak of the coronavirus epidemic. The virus crisis accelerated the erosion of the liberal world order, sharpened the antagonism between the great powers, especially the US and China, and highlighted the vulnerability of the production chains that had been outsourced to the Far East in the hope of cheap labour. Crisis scenarios and forecasts were drawn up, and prominent scientists and researchers expressed the view that there would be no return to the world before the virus. The virus crisis has also highlighted the failure of governments that have not invested in community infrastructure and have neglected public knowledge. It has also shown that government institutions need experts, not loyal mamelukes, to solve public policy problems arising from the crisis.

The coronavirus is the most pressing challenge of this century so far, and in responding to it, localism is being valorised as a crucial centre of solidarity and problem-solving. Forecasters fear that rising inequalities and the erosion of family savings could trigger a wave of political discontent that is more angry and violent than ever before. The majority of people will not be able to manage their children's digital education and work from home without a separate room and computing infrastructure, so governments will need to develop special programmes to address this, and people's health and the capacity of public health to cope will come to the fore. 


\begin{abstract}
The pandemic crisis has provided a new argument for those who argued for the reinvention of the state and the importance of governments' ability to act quickly to deal effectively with natural and economic crises. In recent decades, many have buried the nation state, arguing that successful responses to global problems in a globalised world cannot be found within the framework of a nation state. The Covid-19 crisis has shown that the nation state remains the first front line for effective action against a crisis that is spreading at an unprecedented global scale and speed. Different countries have followed different crisis management strategies and very significant differences in contagion rates have emerged. The crisis has reassessed the role of nation states and borders, which already played an important role in receiving migration flows.
\end{abstract}

Keywords: coronavirus epidemic, crisis, nation-state, government, constitutionality

\section{A globális erőtér átrendeződése}

Válság idején minden politikai rendszer kivételes felhatalmazást ad a végrehajtó hatalomnak, hiszen a hatályos törvények keretein belül nem lehetséges szembenézni az új és gyorsan változó kihívásokkal. Az amerikai alapító atyák egyike, Alexander Hamilton, aki nagyon félt a központi kormányzat túlzott hatalmától, úgy gondolta, hogy vészhelyzet idején fel kell függeszteni a fékek és ellensúlyok rendszerét. Az alkotmányos demokrácia akkor kerül veszélybe, ha a rendkívüli helyzet elmúltával sem áll helyre a jogállami rend.

A második világháborút követően talán nem volt egyetlen esemény sem, amely olyan hatást gyakorolt a világ országaira, mint a koronavírus-járvány kirobbanása. A globalizált, hálózatokba szervezett világban az egyik legnagyobb értéknek számító mobilitást, utazást és személyes érintkezéssel járó tevékenységet a nemzeti kormányok válságkezelő intézkedései befagyasztották. A máskor emberekkel zsúfolt utcák, terek, üdülőövezetek kiürültek, az emberek a lakásaikba kényszerültek, még a digitálisan írástudatlanok is megpróbáltak felcsatlakozni a világhálóra. A tömegkommunikáció és a közösségi média fókuszába a válságstábok napi jelentései kerültek, a tőzsdei hozamgörbék szerepét az egyes országok fertőzöttségi és halálozási mutatói vették át. Sok gyárban leállt a termelés, munkahelyek milliói kerültek veszélybe, az iskolák átálltak a digitális oktatásra, szülők millióinak kellett szerte a világban visszaülni a virtuális iskolapadba. A jövő még bizonytalanabbá, kiszámíthatatlanabbá vált, mint korábban, félelem költözött az emberek, különösen az idősebb generációk lelkébe. A COVID-19 vírus által generált válság reflektorfénybe állította a korábbi liberális világrend összeomlását és a Pax Americana végóráit. Egyesek szerint újra kétpólusú világ fog kialakulni: egy Amerika-központú és egy Kína-központú. Bár Kína gazdasági mérete elérte az amerikai gazdaság $2 / 3$-át, de a „kemény hatalom”, a katonai, pénzügyi és információs potenciál tekintetében Amerikának számottevő az előnye Kínával szemben.

A vírus-válság felgyorsította a liberális világrend erózióját, kiélezte a nagyhatalmak, különösen az USA és Kína közötti ellentéteket, és rávilágított az olcsó munkaerő reményében Távol-Keletre kihelyezett termelési láncolatok sérülékenységére. Válságforgatókönyvek és prognózisok készültek, neves tudósok és kutatók fejtették ki a véleményüket arról, hogy nincsen visszatérés a vírus előtti világba. Eric Klinberg, ${ }^{1}$ a New York-i Institute for Public Knowledge professzora szerint a koronavírus-világjárvány a piaci társadalommal és a hiper-individualizmussal kapcsolatos romantika végét jelentheti. A tudósok prognózisa szerint a vírus hatására az emberek változtatni fognak a korábbi szokásaikon és viselkedésükön, kevesebbet fognak utazni, átalakítják a táplálkozási és fogyasztási szokásaikat, kevesebb erőforrást fognak elhasználni. A pénzhajhászás helyett előtérbe kerülhet az otthoni dolgozás, a tárgyaktól való függés helyett a személyes törődés, az improvizáció és a kreativitás kultúrája pedig a nyertese lehet a válságnak. A családok és a nemzetek is nagyobb figyelmet fordítanak majd az önellátásra. A válság idején és következtében nagyobb megbecsülést kapnak a kutatók, az orvosok és a kórházi személyzet, felértékelódik a telemedicina, és fokozott támogatásra számíthat a családi gondozás intézménye is.

A vírus-válság rávilágított arra is, hogy kudarcra vannak ítélve azok a kormányzatok, amelyek nem ruháztak be a közösségi infrastruktúrába, és elhanyagolták a közszolgálati tudást. Az is kiderült, hogy a kormányzati intézményeknek szakértőkre, és nem lojális mamelukokra van szükségük a válsághelyzetből fakadó közpolitikai gondok megoldása során. A koronavírus ennek az évszázadnak eleddig a legsürgetőbb kihívása, amelynek megválaszolása során felértékelődik a lokalitás, mint a szolidaritás és a problémamegoldás egyik meghatározó centruma. A prognózisok tartanak attól, hogy a növekvő egyenlőtlenségek és a családok megtakarításainak elapadása miatt minden korábbinál dühösebb és erőszakosabb politikai elégedetlenségi hullám indulhat el. Az emberek többsége különszoba és számítástechnikai infrastruktúra hiányában nem tudja megoldani a gyerekek digitális iskoláztatását és az otthoni munkavégzést, ezért erre a kormányoknak speciális programokat kell kidolgozni, és elötérbe fog kerülni az emberek egészségi állapota és közegészségügy teherbíró képessége.

Coronavirus Will Change the World Permanently. Here's How. Elérheto": https://www.politico.com/news/magazine/2020/03/19/coronaviruseffect-economy-life-society-analysis-covid-135579. 


\section{A COVID-válság hatása a politikai rendszerre és az államra}

A pandémiás válság újabb érvet adott azoknak a kezébe, akik az állam újrafelfedezése mellett érveltek, ${ }^{2}$ és a kormányzatok gyors cselekvőképességét rendkívül fontosnak tartották a természeti és gazdasági válságok hatékony kezelésében. Az elmúlt évtizedekben sokan temették már a nemzetállamot, mondván, hogy a globalizált világ globális problémáira nem lehet nemzetállami keretek között sikeres válaszokat találni. ${ }^{3}$ A COVID-19 válság megmutatta, hogy egy világméretű és példátlan sebességgel terjedő válság elleni eredményes fellépés elsődleges frontvonala a nemzetállam maradt. Az egyes országok eltérő válságkezelési stratégiát követtek, és nagyon jelentős különbségek alakultak ki a fertőzöttségi mutatókban. A válság felértékelte a nemzetállamok és a határok szerepét, amelyek már a migrációs hullámok fogadása idején is fontos szerepet játszottak. ${ }^{4}$

A parlamentáris demokráciákról szóló elemzések a válságokat megelőzően is a végrehajtó hatalom erőteljes prezidencializálódását ${ }^{5}$ jelezték. A parlamentekkel szemben a kormányoknak, de különösen a kormányfóknek fokozatosan nőtt a formális és informális hatalmuk a kormányzati döntések meghozatalában. A prezidencializálódási folyamatok elősegítették a gyors kormányzati döntések meghozatalát, ugyanakkor csökkent a kormányzatok parlament általi ellenőrizhetősége, és lehetővé vált a karizmatikus vezetők felemelkedése, egyfajta „vezérdemokrácia” ${ }^{\circ}$ kialakulása.

A globális válság átformálta az alkotmányos intézmények egymáshoz való viszonyát is. Az elmúlt évtizedek alapjogvédelmi fundamentalizmusának térnyerése számos szerzőt arra ösztönzött, hogy alapos kritikát gyakoroljon a nemzetközi „mainstream”-mé vált bírói aktivizmus felett. Külföldi és hazai szerzők egyaránt azt állították, hogy ,jurisztokratikus hatalomgyakorlás"7 alakult ki, vagyis a bíróságok, de leginkább az alkotmánybíróságok kezébe került át a társadalom irányítása azáltal, hogy számos esetben a törvényhozás hatáskörébe tartozó kérdésekben hoztak döntéseket. Mindezen fo-

\footnotetext{
2 Fukuyama, Francis (2005): Államépítés. Kormányzás és világrend a 21 . században. Budapest, Századvég Kiadó; Stumpf István (2014): Erôs állam - alkotmá nyos korlátok. Budapest, Századvég Kiadó; Mickletwait, John - Wooldridge, Adrian (2014): The Fouth Revolution. The Global Race to Reinvent the State. New York, Penguin Press

${ }^{3}$ Pongrácz Alex (2019): Nemzetállamok és új szabályozó hatalmak a globális erótérben - avagy megszelidithetó-e a globalizáció? Budapest, Dialóg Campus. 77. ${ }^{4}$ Baudet, Thierry (2012): A határok jelentősége. Budapest, Századvég Kiadó.

${ }^{5}$ Poguntke, Thomas - Webb, Paul (eds) (2005): The Presidentialization of Poli tics - A Comparative Study of Modern Democracies. Oxford, Oxford University Press; Tanács-Mandák Fanni (2014): A politika prezidencializációja - Magyarország, Olaszország. Pro Publico Bono: Magyar Közigazgatás, 4. sz. 110-119. ${ }^{6}$ Körösényi András (2019): Max Weber és az Orbán-rezsim. Plebiszciter vezér demokrácia Magyarországon. In: Körösényi András (2019): Manipuláció és demokrácia. Politikaelméleti tanulmányok. Budapest, Gondolat Kiadó.

7 Hirschl, Ran (2004): Towards Juristocracy. The Origins and Consequences of the New Constitutionalism. Boston, Harvard University Press; Pokol Béla (2017): A jurisztokratikus állam. Budapest, Dialóg Campus Kiadó.
}

lyamatok mellett, erős globális támogatással felgyorsult az európai és a nemzetközi jog alkotmányosítása, amely a nemzetállamok feletti globális alkotmányjog megteremtését célozta. A globális alkotmányos oligarchia empirikusan megalapozott víziójával fenyegetó megközelítést többen kritizálták, ${ }^{8}$ egyebek mellett azzal érvelve, hogy az európai alkotmányos térség többszintûvé alakult, az európai és tagállami alkotmányos elvek fejlesztik, és egyben korlátozzák egymást. Az alapjogvédelem és az alkotmánybíróságok szerepköréról folytatott vita azért érdekes, mert válsághelyzetekben a kormányzatoknak adott parlamenti felhatalmazás alkotmányos határainak átlépéséről az alkotmánybíróságok hivatottak dönteni. A taláros testületek legitimitása meghatározó jelentőségú lehet a rendkívüli állapot idején hozott kormányzati lépéseket értékelő alkotmányos döntések elfogadásában.

Az elmúlt évtizedek alkotmányos gondolkodásának fó sodrát a jogi konstitucionalizmus jelentette, amely a politikai közösség legfontosabb döntéseinek kialakításában meghatározó szerepet biztosított az írott alkotmányra támaszkodó bírósági alapjogvédelemnek. ${ }^{9}$ Ezzel szemben a politikai konstitucionalizmus a törvényhozás és a bíráskodás viszonylatában a szuverenitás elsődleges letéteményeseként fellépő, a politikai döntéseket meghozó parlamentet tekinti a közösségi cselekvés elsődleges, és a végső szó kimondására hivatott fórumának, korlátozottabb szerepkört szánva a bírói testületeknek a közösség életét alapvetően befolyásoló alkotmányos jelentőségű kérdések eldöntésében. ${ }^{10} \mathrm{~A}$ hazai változások értékelését illetően két élesen szembenálló felfogás alakult ki. Az egyik képviselői szerint a magyar alkotmányosság elmozdult a jogi konstitucionalizmustól a politikai konstitucionalizmus irányába. ${ }^{11}$ A másik megközelítés szerint „a jelenlegi magyar gyakorlat nem a politikai konstitucionalizmus megnyilvánulása". ${ }^{12}$ Újabban a politikai konstitu-

\footnotetext{
${ }^{8}$ Chronowski Nóra (2015): Globális vagy lokális alkotmányosság? Jogelméleti Szemle, 4. sz. 19-31.; Drinóczi Timea (2015): Jurisztokrácia és az alkotmányoligarchia vagy a többszintû alkotmányosság és alapjogvédelem. Reflexiók Pokol Béla írására. Jogelméleti Szemle, 4. sz. 32-45.

${ }^{9}$ A jogi konstitucionalizmus átfogó bemutatását adja: András Sajó - Renáta Uitz (2017): The Constitution of Freedom. An Introduction to Legal Constitutionalism. Oxford, Oxford University Press.

${ }^{10}$ A politikai konstitucionalizmus egyik legátfogóbb kifejtését Richard Bellamy könyve adja. Bellamy, Richard (2007): Political Constitutionalism: A Republican Defence of the Constitutionality of Democracy. Cambridge, Cambridge University Press. A két alkotmányos megközelítés összebékítésére tesz kísérletet: Gardbaum, Stephen (2013): The New Commonwealth Model of Constitutionalism: Theory and Practice. Cambridge, Cambridge University Press; Erdős Csaba (2016): Parlamenti autonómia. Aktustani elemzések az Országgyülés jogállásáról és hatáskörérôl. Budapest, Gondolat Kiadó.

Pócza Kálmán (2012): Alkotmányozás Magyarországon és az Egyesült Királyságban. Kommentár, 5. sz. 35-50.; Antal Attila (2013): Politikai és jogi alkotmányosság Magyarországon. Politikatudományi Szemle, 22. évf. 3. sz. 48-70.; Stumpf (2014): i. m. 244-249.

2 Kovács Ágnes álláspontja, hogy „a politikai konstitucionalizmus fogalma nem alkalmas annak a gyakorlatnak a leírására, amely a magyar politikai intézményrendszer és elsősorban az Alkotmánybíróság múködésébőll rajzolódik ki napjainkban. Igy azt is állítom, hogy a magyar gyakorlat félreértésén alapulnak azok az álláspontok, amelyek a törvényhozás és az alkotmánybíráskodás kapcsolatában 2010 után bekövetkező változásokat olyan modellváltásként értékelik, amely szerint a korábban uralkodó jogi konstitucionalizmust felváltotta a politikai konstitucionalizmus konstrukciója.” Kovács Ágnes (2015): A passzív nem
} 
cionalizmus kritikája az illiberális demokráciához kapcsolt „illiberális alkotmányosság” koncepciójában jelenik meg. ${ }^{13}$ Álláspontjuk szerint a populista politikai többség önkorlátozás nélküli magatartásával átalakítja a liberális alkotmányosságot illiberálissá, foglyul ejtve az alkotmányosságot és magát az alkotmányt is a formális és informális alkotmánymódosításokkal, valamint az Alkotmánybíróság elfoglalásával. Az „illiberális alkotmányosságot” véleményük szerint a politikai alkotmányosság, és az erôsen érzelmi alapokon álló nemzeti identitás koncepciója támogatja. Annak ellenére, hogy a magyar és a lengyel jogrendszer is erósen be van kötve az Európai Unió jogrendszerébe, mégis ezek a folyamatok a jogállam eróziójához és autoriter rezsimek kialakulásához vezetnek ezekben az országokban. Más szerzők ${ }^{14}$ ezt a politikát cezáriánus politikának nevezték el, amely három pilléren nyugszik: (1) patronázs politika, (2) az állam foglyul ejtése, (3) identitáspolitika. A parlamenti többség a politikai kommunikációban barátra és ellenségre osztja fel a társadalmat, és a gazdaság múködtetésében kulcsszerepet kapnak a patronázs hálózatok, amelyek foglyul ejtik az államot. Ezeknek a dominánsan liberális, alapjogvédő megközelítéseknek a legfontosabb állítása, hogy mind a politikai konstitucionalizmus, mind a nemzeti és alkotmányos identitás teóriája csupán álca a rezsim autoriter természetének és múködésének elrejtésére.

Ezzel a felfogással szemben a 2010-es magyarországi „fülkeforradalom” a politikai alkotmányosság győzelmét jelentette. Az alkotmánybírósági aktivizmust felváltotta a kétharmados többségen alapuló (super majority), parlamenti szupremáciára épülő aktivizmus. A Fidesz stratégiai döntéshozói már nagyon régóta készültek arra, hogy a status quo gazdasági, politikai, szellemi elitje által kialkudott, kompromisszumokra épülő rendszert szétverjék, a „megalvadt posztkommunista struktúrák"15 erejét megtörjék. Úgy vélték, hogy az alkotmányos berendezkedé-

puha, avagy miért nem igazolható az Alkotmánybíróság gyakorlata a politikai konstitucionalizmus alapján? In: Gárdos-Orosz Fruzsina, Szente Zoltán (szerk.) (2015): Jog és politika határán. Alkotmánybiráskodás Magyarországon 2010 után. Budapest, HVG-ORAC. 213.

13 Timea Drinóczi - Agnieszka, Bien-Kacala (2019): Illiberal Constitutionalism: The Case of Hungary and Poland. German Law Journal, No. 20. 1140-1166.; Tímea Drinóczi (2020): Hungarian Abuse of Constitutional Emergency Regimes - Also in the Light of the COVID-19 Crisis. In MTA Law Working Papers. Vol. 7. No. 13. pp. 1-26.

${ }^{14}$ Sata-Ireneusz, Robert - Karolewski, Pawel (2019): Cesarian politics in Hungary and Poland. East European Politics, Vol. 36. No. 2. pp. 206-225. https:// www.tandfonline.com/doi/full/10.1080/21599165.2019.1703694; András Sajó (2018): The Constitution of Illiberal Democracy as a Theory About Society. Polish Sociological Review, No. 4. 395-412

${ }^{15}$ A fogalom bevezetése a politikai diskurzusba Tellér Gyulához köthető, aki így jellemezte az első szabadon választott kormányt leváltó szocialista-liberális koalíciót. „Az 1994-ben koalícióra lépő felek mögött hatalmas gazdasági és társadalmi erők álltak. Az egyik oldalon a pénzügyi-igazgatási apparátus a két évtized alatt a valutaalapi recept szerint felépített $\mathrm{s}$ a mindenkori kormányok mozgásterét megszabó gazdaságmúködtető- és finanszírozó konstrukcióival, a három uzsorakörrel, a másikon az MSZP pártklientúrája a maga jelentős vagyoni és kapcsolati erőt koncentráló hálójával, a »megalvadt struktúrákkal «. A felszínen ezekből a mélyben múködő s az egész mozgást meghatározó erókből viszonylag kevés látszott." Tellér Gyula (1999): Hatalomgyakorlás az MSZP-SZDSZ koalíció idején. Budapest, Kairosz. 51. sen belül súlyos torzulások történtek, jelentős mértékben korlátozva a kormányok cselekvőképességét. Ezért vissza kell metszeni a hatalommegosztás túlzásait, helyre kell állítani a választott parlament szupremáciáját, erős államot és hatékony közigazgatást kell építeni. Álláspontjuk szerint a Magyarországot ért európai támadások hátterében a kormány ama törekvése állt, hogy a politikai kérdéseket repolitizálja, és a többségi választói felhatalmazást érvényesítse. Ez szembement az uniós politika legfőbb áramlatával, a politikai kérdések eljogiasításával. „Az emberi jogi gondolkodás extrém dominanciájával és a többségi elv érvényesítésének egyértelmű korlátozásával jellemezhető európai politika élesen szemben áll az egyetlen párt alkotta parlamenti többség teljes szuverenitásán alapuló elvvel." Valójában tehát a politikai konstitucionalizmus fundamentális tartópillérét a parlamenti szupremácia adja. Az Alaptörvény és módosításai egyértelműen a korábbi alapjogi aktivizmus zsinórmértékéül szolgáló „láthatatlan alkotmány” leváltását, majd egyre inkább a végrehajtó hatalom (élén a miniszterelnök) hatáskörének kiszélesítését szolgálták. A válságkezelés és a rendkívüli helyzetekben alkalmazandó alapjogkorlátozás kormányzati filozófiája ezeken a megfontolásokon nyugodott.

\section{Kormányzati cselekvési kényszer-egészségügyi vészhelyzet kezelése Magyarországon}

A koronavírus-válság Magyarországon három egymást követő parlamenti választáson alkotmányozó többséget szerzett magabiztos kormánypártot (Fidesz-KDNP) és rendkívül erôs politikai és alkotmányos felhatalmazással rendelkező kormányföt talált, akit nem rendített meg az ellenzék sikere az önkormányzati választásokon. A kormányzó erôk, a kezdeti bizonytalankodás után, a migrációs hullám kezelésében szerzett tapasztalatokat felhasználva vágtak bele a rendkívüli helyzet kezelésébe. Az önkormányzati választások eredményeként az ellenzék a fóvárosban és számos nagyvárosban megszerezte a hatalmat, és elérkezettnek látta az időt annak bizonyítására, hogy a kormány nem képes a válságot kezelni, csupán a saját hatalmát akarja tovább növelni a rendkívüli intézkedések bevezetésével. 2020. március 11-én a Kormány Magyarország egész területére az Alaptörvény 53. cikke szerinti veszélyhelyzetet hirdetett ki „az élet- és vagyonbiztonságot veszélyeztető tömeges megbetegedést okozó humánjárvány következményeinek elhárítása, a magyar állampolgárok egészségének és életének megóvása érdekében". ${ }^{17}$ Ezáltal a Kormány rendkívüli felhatalmazást teremtett arra, hogy a járvány által okozott veszélyhelyzetet rendeleti kormányzással hárítsa el, felfüggessze egyes törvények alkalmazását vagy eltérjen bizonyos tör-

${ }^{16}$ Pócza (2012): i. $m$

17 40/2020. (III. 11.) Korm. rendelet. 
vényi rendelkezésektől, illetve egyéb rendkívüli intézkedéseket léptessen hatályba. A világ számos országában a kormányok hasonló döntéseket hoztak, a rendkívüli felhatalmazások szüikségességét pedig széles körü egyetértés övezte. A hazai politikai vitát az váltotta ki, hogy a koronavírus elleni védekezésról szóló törvény ${ }^{18}$ nem tartalmazott konkrét időbeni korlátot, azonban egy alkotmányos klauzula deklarálta, hogy a Kormány a veszélyhelyzetet köteles megszüntetni, „ha kihirdetésének feltételei már nem állnak fenn"19. Az ellenzék azzal vádolta a Kormányt, hogy örök idókre be akarja betonozni a hatalmát, és fenn akarja tartani a rendeleti kormányzást, a miniszterelnök pedig - szólt az ellenzéki érvelés politikai fegyverként akarja használni a pandémiás válságot az ellenzékkel és az óket támogató médiával szemben. A politikai játszma végül úgy alakult, hogy a Kormány nem épített be konkrét időkorlátot, ezért az ellenzék nem szavazta meg a koronavírus elleni védekezésról szóló törvényt. A kooperáció, a nemzeti összefogás helyett maradt a konfrontáció és a politikai ellenfelek diabolizálása. A kormánypártok „lehazaárulózták” az ellenzéket, az ellenzéki pártok pedig azzal vádolták a kormányfőt, hogy diktatúrát akar bevezetni, és politikai karanténba akarja kényszeríteni Magyarországot. Nem zárható ki a politikai játszma olyan értelmezése, hogy a Fidesz csapdát állított az ellenzéknek, amelybe az be is sétált, bizonyítva, hogy krízishelyzetekben sem lehet számítani az együttmúködésére. A kormánypártok kétharmados parlamenti többsége és a kormányfó abszolút autoritása nem tette volna szükségessé a húrok feszítését, de a felhatalmazás vártnál korábbi visszaadásával világossá vált a politikai tóke begyújtésének a szándéka.

A közvélemény-kutatások szerint nem volt még példa arra, hogy az emberek közel kilencven százaléka ilyen aktívan foglalkozzon egy témával, mint most a koronavírussal. A járvány alatt a Fidesz stabilizálni tudta a szavazótáborát, amelyben szerepe lehetett annak, hogy támogatóinak 91 százaléka elégedett azzal, ahogyan a kormány a koronavírus-válságot kezelte. Egyértelmúen növekedett az Orbán Viktor koronavírus-járvány menedzselésével elégedettek aránya: két hónappal a járvány kitörése után a magyar társadalom 62 százaléka elégedett volt a miniszterelnök munkájával. ${ }^{20}$

A válság lehetőséget teremtett a ciklus felénél tartó kormányzó pártok és a parlamenti választásokra közös stratégiával készülő ellenzéki pártok számára az erőfelmérésre. A kormányfö - élve a felhatalmazás adta lehetőséggel - további lépéseket tett a hatalom centralizálásának irányába, a válság terhei egy részének az önkormányzatokra történt áthárításával pedig növelte a települések függőségét a központi közigazgatástól.

\footnotetext{
18 2020. évi XII. törvény a koronavírus elleni védekezésről.

${ }^{19}$ Alaptörvény 54. cikk (3) A különleges jogrendet a különleges jogrend bevezetésére jogosult szerv megszünteti, ha kihirdetésének feltételei már nem állnak fenn. ${ }^{20}$ Nézőpont Intézet. 2020. június 24-26 közötti, ezer fős közvéleménykutatás.
}

A polgármesteri jogköröket csorbító törvényjavaslat ${ }^{21}$ visszavonása viszont azt mutatta, hogy a miniszterelnök - érzékelve az ellenállást saját pártjában is - jobbnak látta, ha nem erőlteti tovább a központosítási törekvéseket az önkormányzati önállóság rovására. Az ellenzék számára is egyértelmúvé vált, hogy a nemzetközi és hazai bírálatok ellenére a kormánypártok és a miniszterelnök lett a koronavírus-válság első fejezetének a politikai nyertese. A relatíve alacsony fertőzöttségi és halálozási mutatók mellett a gazdaság múköooóképes maradt, még az EU is erôteljes gazdasági növekedést prognosztizál a következő évre. Feltehetően ezek a fejlemények is közrejátszhattak abban, hogy az ellenzék domináns erői mielőbb megállapodjanak a választási együttmúködés legfontosabb prioritásaiban, azt remélve, hogy az egységes fellépés révén megnyerhetik a 2022-es parlamenti választást, és leválthatják az Orbán-kormányt.

\section{A különleges jogrend bevezetésével kapcsolatos alkotmányos aggályok - az Alkotmánybíróság szerepe}

A különleges jogrend bevezetése ritka, mint a fehér holló a modern alkotmányos demokráciákban (Franciaország 1961-ben, Portugália 1975-ben, Spanyolország 2010ben, a párizsi merénylet után Franciaországban 2015ben, a tömeges bevándorlás okozta válsághelyzet, hazánkban 2015 óta). Magyarországon az Alaptörvény hatféle különleges jogrendet szabályoz, nagy részletességgel, de kritikusai szerint számos ponton elhibázottan, és nem eléggé átgondoltan. ${ }^{22} \mathrm{~A}$ különleges jogrend alkotmányos jelentőségét az adja, hogy az az alapjogok szokatlan és rendes körülmények között elfogadhatatlan mértékú korlátozásával jár. A közhatalmi jogosítványok erős központosításával újraszabályozza a hatalomgyakorlás rendjét, egyfajta „alkotmányos diktatúrát” vezet be. Mindezt az teszi indokolttá, hogy a minősített időszak társadalmi, gazdasági következményei rendkívül súlyosak, és ezek elhárítására a kormányzati szervek különleges hatásköröket kapnak, amelyeket alkotmányos ellenőrzés mellett, ideiglenesen, arányosan és célhoz kötötten gyakorolhatnak. Az Alaptörvény 54. cikke részletesen szól arról, hogy bizonyos alapjogokat ('́gy az élethez és az emberi méltósághoz való jogot, a kínzás tilalmát, az ártatlanság vélelmét, a védelemhez való jogot, a visszaható hatályú büntető jogalkalmazás tilalmát, a ne bis in idem elvét) és az Alaptörvény alkalmazását különleges jogrend idején sem lehet felfüggeszteni. A veszélyhelyzet idején hozott rendkívüli intézkedések időbeli hatályának meghosszabbítása pedig parlamenti jóváhagyáshoz kötött. Az alkotmányos ellenőrzés leg-

${ }^{21}$ A 2020. március 31-én benyújtott T/9934. számú törvényjavaslat 36. §-át a kormány április 1 -jén visszavonta.

Szente Zoltán (2020): A 2020. március 11 -én kihirdetett veszélyhelyzet alkotmányossági problémái. MTA Law Working Papers, 9. sz. 12., 14. 
fontosabb szerve az Alkotmánybíróság, amelynek múködése a különleges jogrend idején sem korlátozható, így az megsemmisítheti az alkotmányos felhatalmazáson túllépő rendeleteket. A különleges jogrend alkotmányos rendszerünk része, olyan önvédelmi mechanizmus, amely az állam múködőképességének fenntartásához és a lakosság megóvásához szükséges.

A Kormány 2020. március 11-i rendeletével hirdette ki a veszélyhelyzetet, amelyet követően számos szükségrendeletet adott ki, esetenként felfüggesztve egyes törvényi rendelkezéseket. Már a veszélyhelyzet kihirdetését is éles szakmai bírálatok övezték, azt állítva, hogy a veszélyhelyzet kihirdetésére alaptörvény-ellenes módon került sor, ezért a veszélyhelyzet során kiadott valamennyi kormányrendelet alaptörvény-ellenes. ${ }^{23}$ Szente Zoltán elemzésében azért tekinti alaptörvény-ellenesnek a veszélyhelyzet rendeleti úton történt kihirdetését, mert arra a tömeges megbetegedést okozó humánjárványra hivatkozással került sor, a magyar jogban azonban a humánjárvány nem tartozik az elemi (természeti) csapás fogalmi körébe, és ipari katasztrófaként sem értelmezhető. Bár a katasztrófavédelmi törvény az említett tömeges megbetegedést egyértelműen olyan eseménynek tekinti, amely alapul szolgálhat a járványveszély kihirdetéséhez, de ez az alkotmányjogász szerint az Alaptörvényben meghatározott helyzetek önkényes kiterjesztése. Sem a katasztrófavédelmi törvény, sem pedig a kormányrendelet nem írhatja felül az Alaptörvényt. Megítélésem szerint nincsen szó az Alaptörvényben meghatározott helyzetek önkényes kiterjesztéséról. Az Alaptörvény 53. cikkének ${ }^{24}$ és a katasztrófavédelmi törvény 44 . $\$ c a)^{25}$ bekezdésének együttes értelmezése alapján alkotmányosan megalapozottnak tekinthető a veszélyhelyzet rendeleti úton történő kihirdetése. A katasztrófavédelmi törvény veszélyhelyzetre vonatkozó fejezete az Alaptörvény 53. cikkét hajtja végre, példálózóan felsorolva a veszélyhelyzetek 11 típusát, köztük a tömeges megbetegedést okozó humánjárványt. Textuális értelmezéssel, de a józan ész értelmezési követelményére alapozva is levezethető az alaptörvényi szabályból a kormány veszélyhelyzeti felhatalmazásának alkotmányossága. A felhatalmazás alkotmányosságának eldöntésében a végső szó természetesen az Alkotmánybíróságé, de a veszélyhelyzet kihirdetéséról szóló kormányrendelet ellen benyújtott alkotmányjogi panasz ${ }^{26}$ a hiánypótlási határidő eredménytelen letelte miatt nem került a testület elé.

$\mathrm{Az}$ Eötvös Károly Intézet is alkotmányjogi vizsgálat alá vonta a magyar kormány válságkezelési gyakorlatát,

\footnotetext{
${ }^{23}$ Szente (2020): i. m. 15.

${ }^{24}$ Alaptörvény, 53. cikk (1) A Kormány az élet- és vagyonbiztonságot veszélyeztető elemi csapás vagy ipari szerencsétlenség esetén, valamint ezek következ ményeinek az elhárítása érdekében veszélyhelyzetet hirdet ki, és sarkalatos törvényben meghatározott rendkívüli intézkedéseket vezethet be.

252011 . évi CXXVIII. törvény a katasztrófavédelemről és a hozzá kapcsolódó egyes törvények módosításáról: 44 . $\$$ ca) tömeges megbetegedést okozó humánjárvány vagy járványveszély, valamint állatjárvány.

${ }^{26}$ IV/673/2020. A veszélyhelyzet kihirdetéséról szóló 40/2020. (III. 21.) Korm. rendelet 1 . \$-a és a 4 . \$-a elleni alkotmányjogi panasz (veszélyhelyzet kihirdetése).
}

amelyet összefoglalóan „átmentett hatalomkoncentrációnak" nevezett. ${ }^{27}$ Szerintük a kivételes jogrend bevezetése nélkül, a fennálló alkotmányos keretek között, lényegesen mérsékeltebb jogkorlátozó intézkedések révén is megoldható lett volna a járványhelyzet kezelése. Úgy vélik, hogy a szabadságjogokat radikálisan felfüggesztő rendeleti kormányzás a Nemzeti Együttmúködés Rendszerének természetéból fakad, amely állandó offenzívára, folyamatos belső hódításra, az autonómia maradékainak karanténba szorítására, majd megsemmisítésre törekszik.

A koronavírus elleni védekezésről szóló 2020. évi XII. törvény (a továbbiakban: felhatalmazási törvény) célja az volt, hogy a Kormány számára lehetővé tegye bármilyen rendkívüli intézkedés megtételét a tömeges megbetegedés megelőzése és a járvány következményeinek elhárítása érdekében. A szakmai kritikák szerint több sebből vérzik ez a törvény, bár garanciális elemeket is tartalmaz, úgymint az Országgyưlés folyamatos tájékoztatása, és a parlament lehetősége a törvény visszavonására, valamint az Alkotmánybíróság akadálymentes múködésének biztosítása. Mégis számos, az alkotmányos alapjogok radikális védelme mellett elkötelezett szerző szerint a felhatalmazási törvény több rendelkezése is alaptörvény-ellenes. ${ }^{28}$ Ilyennek tekintik azt a rendelkezést is, amely tartalmi értelemben korlátlan szükségrendeleti felhatalmazást ad a Kormánynak arra, hogy a veszélyhelyzetben hozott kormányrendeletek hatályát - saját hatáskörben eljárva - a veszélyhelyzet végéig meghosszabbítsa. Szente Zoltán tanulmányában olyan eszmefuttatással is találkozhatunk, amely azt vizionálja, hogy a magyar törvényhozás valóságos „öngyilkosságot” követett el, mert úgy mondott le az utólagos kontroll jogáról, hogy elvileg visszavonhatatlan folyamattá tette a kivételes felhatalmazást.

Halmai Gábor alkotmányjogász még ennél is erôsebben fogalmaz, amikor a Hitlernek adott felhatalmazási törvényhez hasonlítja a koronavírus elleni védekezésről elfogadott törvényt. ${ }^{29}$ A 2010 utáni alkotmányos berendezkedés legradikálisabb kritikusa egy másik blogbejegyzésében ${ }^{30}$ azt állítja, hogy a rendes bíróságok múködését felfüggesztették, büntető ügyszakban az ügyész tejhatalmat kapott, az egészségügyi intézmények rendészeti irányításával egyfajta katonai hatalomátvétel előkészítése zajlik, és az alsóbb szintú bíróságok bezárása miatt az

\footnotetext{
${ }^{27}$ Eötvös Károly Intézet: Átmentett hatalomkoncentráció: koronavírus-leltár. A magyar kormány válságkezelésének alkotmányjogi értelmezése. Elérhető: http://ekint.org/lib/documents/1592554960-EKINT_Koronavirus-leltar_ elemzes.pdf.

${ }^{28}$ Szente (2020): i. m. 18

29 "This was spectacularly proved on 30 March 2020, when the Orbán government introduced its Enabling Act[2] similar to Hitler's Ermächtigungsgesetz of 1933. The Act gives dictatorial powers under cover of declaring a state of emergency to fight COVID-19:" Gábor Halmai: How COVID-19 Unveils the True Autocrats: Viktor Orbán's Ermächtigungsgesetz. Elérhető: http://www. iconnectblog.com/2020/04/how-covid-19-unveils-the-true-autocratsviktor-orbans-ermachtigungsgesetz/.

${ }^{30}$ Halmai, Gábor - Scheppele, Kim Lane: Don't Be Fooled by Autocrats!: Why Hungary's Emergency Violates Rule of Law. Elérhető: https://verfassungsblog. de/dont-be-fooled-by-autocrats/.
} 
Alkotmánybíróság múködése is értelmetlenné vált. Ezek a valós alapot nélkülöző állítások még a korábban több nemzetközi perben a kormánnyal szemben álló felet képviselő Karsai Dániel számára is túlmentek a tényszerú kritika határain. ${ }^{31}$ Bár neki is számos alkotmányos aggálya van a különleges jogrend szabályozásával kapcsolatban, de határozottan állítja, hogy a rendes bíróságok múködnek, az ügyész csak járványügyi kockázat esetén halaszthat, a Honvédség csupán a stratégiailag kiemelt ágazatokban jelent meg a szakmai koordináció elősegítése céljából, az Alkotmánybíróság pedig rendszeresen fogad beadványokat a veszélyhelyzet idején is.

A Velencei Bizottság 2020. májusi jelentésében foglalta össze azokat a szempontokat, amelyeket a különleges jogrend bevezetésével és múködésével kapcsolatban figyelembe kell venni. ${ }^{32}$ A magyar kormányzat úgy értékelte, hogy az ebben megfogalmazott jogállami követelményeknek a hazai szabályozás megfelel. A kormányoldali nézőpont szerint nem politikai okok, hanem a katasztrófa elhárítása miatt volt szükség a különleges jogrend kihirdetésére. Az emberi jogokra nem az állam, hanem a közegészségügyi veszély jelent fenyegetést, az államnak éppen az a feladata, hogy múködésbe hozza a védelmi mechanizmusait, megvédje polgárainak az élethez és az emberi méltósághoz való alapjogát. A járvány nem egyenlő mértékben sújtja a társadalom tagjait, az idősek és a betegek a legsérülékenyebb társadalmi csoportok, akikre az állam védelmi kötelezettsége a leginkább kiterjed. Az állam tehát nem előidézője az emberi jogi sérelmeknek, hanem teljes arzenáljával arra törekszik, hogy polgárai életét és egészségét minél szélesebb körben megóvja.

Az ellenzéki sajtó hosszú listákat közölt ${ }^{33}$ arról, hogy a kormányzat milyen módon élt vissza a rendkívüli felhatalmazással, hogyan használta fel a kínálkozó lehetőséget saját klientúrájának gazdasági megerősítésére, és a politikai rendszer további centralizálására. Az Eötvös Károly Intézet a már említett elemzésében vette számba azokat az alkotmányos problémákat, amelyek a koronavírus-válság kezelése kapcsán felmerültek. Számos ügy jutott el az Alkotmánybíróság elé, amelyek egy részében döntés is született (a gépjármúadó elvonása a helyi önkormányzatoktól, az önkormányzati tulajdonjog korlátozása veszélyhelyzetben, valamint a rémhírterjesztés). ${ }^{34}$

\footnotetext{
${ }^{31}$ Karsai, Dániel: Let's not fool ourselves either!: Some remarks on Professor Halmai's and Professor Scheppele's blogpost. Elérhetö: https://verfassungsblog.de/letsnot-fool-ourselves-either/.

${ }^{32}$ Elérhető: https://www.venice.coe.int/webforms/documents/?pdf=CDLPI(2020)005rev-e.

${ }^{33}$ Tóth Richárd - Dobszay János: Orbán úgy adja vissza a felhatalmazást, hogy sok mindent megtart belőle. $H V G, 2020$. 05. 27. https://hvg.hu/360/ 20200527_A_szuksegtelen_plusz.

${ }^{34}$ II/822/2020: Magyarország 2020. évi központi költségvetésének a veszélyhelyzettel összefüggő eltérő szabályairól szóló 92/2020. (IV. 6.) Korm. rende let 4. \$-a elleni utólagos normakontroll indítvány (gépjármúadó, önkorm. tulajdonjog). Döntés: 3234/2020. (VII. 1.) AB határozat. IV/699/2020 A Büntető Törvénykönyvról szóló 2012 . évi C törvény $337 . \$(2)$ bekezdése elleni alkotmányjogi panasz (rémhírterjesztés). Döntés: 15/2020. (VII. 8.) AB határozat.
}

Az AB-hoz 2020. július közepéig, a törvénykezési szünet kezdetéig összesen húsz, a járványügyi vészhelyzettel kapcsolatos beadvány érkezett, amelyekből kilenc idegenrendészeti ügyben hozott határozat felülvizsgálata, kiutasítás járványügyi szabályszegés miatt. Érdemi határozat mindeddig az önkormányzati és a rémhírterjesztési ügyben született, az ügyek döntő többsége még folyamatban vagy hiánypótlás alatt van. Az $\mathrm{AB}$ az önkormányzati gépjármúadó tekintetében, a hatásköri korlátok miatt érdemi vizsgálat nélkül visszautasította az indítványt, a nemzetközi szerződésbe ütközést tekintve pedig érdemi vizsgálat után elutasította azt. A határozatot soron kívül, több párhuzamos indoklással, különvélemény nélkül hozta meg a testület. Az utólagos normakontroll iránti kérelmet 54 ellenzéki képviseló nyújtotta be. A rémhírterjesztéssel kapcsolatos ügyben viszont, személyes érintettségre hivatkozással egy ügyvéd adott be alkotmányjogi panaszt. $\mathrm{Az} \mathrm{AB}$ ebben az esetben sem találta alkotmánysértőnek a Büntető Törvénykönyvről szóló 2012. évi C. törvény 2020. március 31-től hatályos 337. $\$(2)$ bekezdését, de a későbbi bírói gyakorlat orientálására megfogalmazott egy alkotmányos követelményt. ${ }^{35}$ További három alkotmányjogi panasszal támadott jelentősebb ügyben (különleges gazdasági övezetek kijelölése, veszélyhelyzeti kormányrendeletek hatályának meghosszabbítása és a közérdekú adatigénylés teljesítésének határideje különleges jogrend alatt) folyamatban van az eljárás az Alkotmánybíróság előtt.

A rendkívüli jogrend megszüntetését, a kabinet parlamenttől kapott felhatalmazásának visszaadását a kormánytöbbség nagy fegyvertényként ünnepelte. Úgy vélték, hogy ez az aktus látványos cáfolata a diktatórikus hatalomgyakorlás vádjának, bizonyítéka annak, hogy Magyarországon múködik az alkotmányos jogállam. Az ellenzék a több mint $400 \$$-t tartalmazó, a veszélyhelyzet megszúnésével összefüggő átmeneti szabályokról és a járványügyi készültségrôl szóló 2020. évi LVIII. törvényben a rendeleti kormányzás állandósítását, a rendkívüli jogrend idején kivételesen és ideiglenesen alkalmazott szabályok tartóssá tételét látta.

A liberális jogvédők kritikájának fókuszában az állt, hogy a járványügyi készültség bevezetésével a Kormány a rendkívüli jogrend elrendelése nélkül is hozhat rendkívüli intézkedéseket, a parlamenti ellenőrzés mellőzésével rendeletben korlátozhatja az egyéni szabadságot. A járványügyi veszélyhelyzet elrendeléséról az országos tisztifőorvos javaslatára, a miniszter elóterjesztése alapján a Kormány dönt. A járványügyi készültség hat hónapig tart, de ennek hatályát a Kormány meghosszabbíthatja,

\footnotetext{
35 „Alkotmányos követelmény, hogy a szándékos búncselekmény csak az olyan tényközlésre terjed ki, amelyről az elkövetőnek a cselekmény elkövetésekor tudnia kellett, hogy az hamis vagy amelyet maga torzított el, és amely a különleges jogrend idején a védekezés akadályozására vagy meghiúsítására alkalmas. Az elkövetés idején vitatott, és csak a későbbiekben hamisnak bizonyuló tények közlése nem vonható a Btk. 337. \$ (2) bekezdésének hatálya alá.” 15/2020. (VII. 8.) AB határozat.
} 
és így a rendeleti kormányzás minden parlamenti ellenőrzés nélkül hosszú ideig fenntartható.

Drinóczi Tímea szerint Magyarországon kialakult egy „illiberális alkotmányosság”, ahol az alkotmányos demokrácia minden eleme, a jogállam, a demokrácia, az emberi jogok megfigyelhető(ek), bár nem érvényesül(nek) maradéktalanul. Az illiberális alkotmányosság nem ellentétje a liberális alkotmányosságnak, és nem egyenlő a tekintélyelvú hatalomgyakorlással. ${ }^{36}$ A kutató arra figyelmeztet, hogy a pandémiás válság kihívást jelent a világ bármely típusú alkotmányosságának és az alkotmányos gondolkodásnak egyaránt. Újra kellene gondolni az alkotmányos értelmezési kereteinket. A rendkívüli idő́k rendkívüli megoldásokat igényelnek, figyelemmel az egyes országok kulturális sajátosságaira, a szociális együttélés alapvető struktúráira, és az alkotmányos demokrácia meghatározó értékeire.

\section{Válság után - válság előtt?}

A pandémiás válság, ha nem is tombol olyan erővel, mint a kitörésekor, velünk élő valóság maradt. A kormányok egy újabb hullám megelózésére ismét a rendkívüli állapot bevezetését, szabadságkorlátozó intézkedések meglépését fontolgatják. A COVID-19 ellenszerének kifejlesztése gőzeróvel folyik, a készülő vakcinákból a nemzeti kormányok és az Európai Unió is több milliós tételt rendelt meg elöre.

Az emberek szemében felértékelődött a biztonság és a stabilitás, a korlátozásokat viszont a társadalom legidősebb és legfiatalabb generációi viselik a legnehezebben. Az idősek és a betegek a legkiszolgáltatottabbak, családi vagy közösségi segítség nélkül, a karantén ideje alatt nem tudnak gondoskodni magukról. A fiatal generációk hozzá voltak szokva a mobilitáshoz és a fogyasztási hedonizmushoz, nehezen viselték a határok lezárását, a szobafogságot és a vásárlási korlátozásokat. Bár az elörejelzések szerint a gazdasági növekedés jövőre beindulhat, de még nagyon sokan nem találtak munkahelyet, és a családok jelentős része is felélte a tartalékjait.

A magyar kormány egyszerre készül a járvány második hullámának terjedését megakadályozni szándékozó korlátozó intézkedésekre, és a gazdaság újraindítását segítő ösztönző lépésekre. A nyári szünet ugyan rövid időre elfedte a gondokat, de a koronavírus-válság első szakaszának társadalmi-gazdasági következményei egyre szélesebb társadalmi rétegek számára nehezítik meg a napi problémák megoldását.

A vírus-válság az eddigi legkomolyabb tesztje a politika stressztürő-képességének, és az alkotmányos jogállam alapjogvédelmi rendszerének. Azok az országok tudják sikeresen kezelni a válságot, ahol az állam erős, és rendel-

\footnotetext{
${ }^{36}$ Tímea Drinóczi (2020): Hungarian Abuse of Constitutional Emergency Regimes - Also in the Light of the COVID-19 Crisis. MTA Law Working Papers. 10. sz. 2.
}

kezik a problémák megoldásához szükséges kapacitásokkal, ahol a polgárok bíznak a közintézményekben és ahol hatékony és kompetens vezetés irányítja az országot. ${ }^{37}$ Történelmi tanulságok azt mutatják, hogy minden nagy válságot igen komoly társadalmi-gazdasági-politikai átrendeződés követett. Most sem lesz másként: változni fog a hatalom globális elosztása, a technológiai cégek tovább növelik a befolyásukat, a válság veszteseinek körében fokozódik a feszültség, de ma még nem látni világosan, hogy ez az indulat ki ellen fog irányulni.

Ha elfogadjuk Fukuyama tételét, miszerint a válságkezelés sikerességét három tényező alapozza meg (kormányzati kapacitás, közbizalom és vezetóképesség), akkor differenciált kép alakul ki a magyar helyzetet illetően. Az Orbán-kormány elkötelezett az erôs állam filozófiája mellett, és az elmúlt évtizedben a közigazgatás centralizációja irányába is határozott lépéseket tett. A kormányzati struktúrán belül a Belügyminisztérium rendelkezik a leghatékonyabb végrehajtási kapacitással, így nem véletlen, hogy a kórházparancsnoki rendszer és az Operatív Törzs múködtetésében is kitüntetett szerepet kapott. Már a migrációs válság is megmutatta, hogy a kormány szívesen alkalmaz rendészeti eszközöket a problémák kezelése során. Több éve húzódik számos alrendszer, köztük az egészségügy és az oktatás átalakítása. A koronavírus-válság éppen ezt a két rendszert érintette legérzékenyebben, hiszen forrás- és feltételhiányos környezetben kellett válaszolniuk a váratlan kihívásokra. A vírus-válság első hullámát az ágazat szereplőinek jelentős áldozatvállalása, és rapid kormányzati beavatkozás révén sikerült kezelni. A kórházi ágyak felszabadítása és a távoktatás igen súlyos társadalmi konfliktusokat is generált. Mindehhez társult az önkormányzati szféra bevonása a közteherviselésbe (a gépjármúadó elvétele), amelyet még a kormánypárti önkormányzatok is komoly érdeksérelemként éltek meg. A közvélemény-kutatások szerint a kormány sikerrel kezelte a válság első hullámát, társadalmi alulnézetből azonban számos feszültség halmozódott fel, amelyet a nyaralás csak időlegesen tompított.

A kormányba és a közintézményekbe vetett bizalmat tekintve rendkívüli mértékben megosztott az ország. Az önkormányzati választás jól jelezte, hogy a főváros és még számos nagyváros lakosságának jelentős része elégedetlen a kormányzó erőkkel. Az ellenzéki győzelmek a kormánnyal való elégedetlenséget szimbolizáló morális lázadások voltak, amelyek, ha párosulnak szociális típusú elégedetlenséggel is, akkor leválthatják a hatalmon lévőket. A kormánypártoknak ugyanakkor nagyon stabil és elkötelezett szavazótábora van, amely a közvéleménykutatások szerint rendkívül elégedett a kormányfó válságmenedzselő munkájával. Amennyiben a vírus-válság nem fordul át gazdasági és szociális válságba, és a kormány konszolidálni tudja a járványveszélyt, akkor talán

\footnotetext{
${ }^{37}$ Fukuyama, Francis (2020): The Pandemic and Political Order. It takes a State. Foreign Affairs, 2020. July/August. https://www.foreignaffairs.com/articles/ world/2020-06-09/pandemic-and-political-order.
} 
még azok bizalmát is elnyerheti, akik pártpolitikai alapon nem szimpatizálnak a kormánypártokkal, de elismerik a válságkezelésben nyújtott teljesítményüket. Ha a növekedés jelentős, 7-9\%-os visszaeséséhez, egyes kiskereskedelmi szektorok és ágazatok ellehetetlenüléséhez, az államháztartási hiány drasztikus megugrásához párosul a vírus-válság második hullámának gazdaságfékező és társadalmi feszültségeket generáló hatása, akkor igen nehéz hónapok elé néz az ország.

Azt senki nem vitatja Magyarországon, hogy olyan vezetője van a kormánynak, aki kézben tartja az adminisztráció múködését, karizmatikus egyéniségével uralja a hazai politikai eröteret, és az elmúlt években a nemzetközi politikában is meghatározó szereplővé vált. Alkotmányosan is megerősített kormányzati pozíciója olyan gravitációs erőteret biztosít számára, amelyet a nagy multinacionális vállalatok is kénytelenek tudomásul venni. Az illiberális paradigma meghirdetésével kiírta magát az európai mainstream-ból, de egy alternatív politikai pólust teremtett, amelyet nem lehet negligálni az európai porondon sem. Politikai erejét és legitimációját a háromszor egymás után elért kétharmados választási győzelem, a négyszeres miniszterelnökség, és a több mint harmincéves élvonalbeli politikai tapasztalat adja. Rendkívül nagy hatalom összpontosul a miniszterelnök kezében, miközben folyamatosan veszítenek kontrollszerepükból az erre rendelt alkotmányos intézmények, és a korábban még fontos szerepet játszó informális visszacsatoló mechanizmusok. Krízishelyzetekben nem csupán eróforrást, hanem komoly rizikófaktort is jelent a kormányozhatóság szempontjából a rendszer ilyen mértékű függősége egyetlen személytől.

A magyar alkotmányos jogállam múködését illetően már komolyabb aggályok merülnek fel. Az alkotmányozó hatalom birtokában a kormányzó pártok igen ritkán vették maguknak a fáradságot arra, hogy a nyilvánosság előtt igazolják a jogi megoldásaik közjót szolgáló jellegét. A kétharmados kormányzás egyik markáns jellemzője az erópolitika alkalmazása az élet minden területén, így a törvényhozásban is. A finoman hangolt jogi megoldások, és netán a kompromisszumok nem Orbán kormányzásának a jellemzői. Így túl sok energiát nem pazaroltak annak igazolására sem, hogy a veszélyhelyzet bevezetésének megvoltak-e az alkotmányos alapjai, mondván, ott az Alkotmánybíróság, tessék normakontrollt kérni. A veszélyhelyzet kihirdetésével kapcsolatos beadvány pedig - mint ahogyan korábban írtam - el sem jutott az érdemi tárgyalásig, így nem ismerhettük meg az Alkotmánybíróság álláspontját a kérdésben. Érdemes megfontolni, hogy miként lehetne a kormány túlhatalmát jelentő ama alkotmányos anomáliát megszüntetni, amely diszkrecionális jogot ad a veszélyhelyzet kihirdetésével, időintervallumának és tartamának meghatározásával kapcsolatban. Egyrészt a kormány veszélyhelyzeti rendeletalkotási jogkörének gyakorlását, a tárgyi hatály alkotmányos követelményeket érvényre juttató pontosabb meghatározásával korlátok közé kell szorítani, ame- lyeket természetesen az Országgyưlés, akár a veszélyhelyzet fennállása alatt is - sarkalatos törvényben - szükség esetén módosíthat. Másrészt a veszélyhelyzet kihirdetésével és az Alaptörvény 53. cikk (2) bekezdése alapján hozott rendeletekkel és intézkedésekkel kapcsolatos utólagos normakontroll esetében az Alkotmánybíróságnak sürgősen kelljen dönteni, hasonlóan a választási ügyekben alkalmazott határidőkhöz. Ha tehát az utólagos alkotmányos felülvizsgálatra jogosultak közül bárkinek problémája van a rendeleti kormányzás fundamentumaival, akkor arra minél előbb szülessen alkotmánybírósági válasz, a későbbi legitimációs viták elkerülése érdekében.

A napjainkban újra lendületet kapó koronavírus-járvány az alkotmányos demokráciák stressztűrő képességének a vizsgája. Válsághelyzetekben mindig feszültség jön létre az polgárok alapjogainak védelme és a közösségi érdekek biztosítása között. Demokráciákban a veszélyhelyzet elmúltával a kormányzat lemond a különleges felhatalmazásáról, diktatúrákban marad a tejhatalom. A válság elmúltával kiállíthatjuk a bizonyítványt, hogy melyik ország milyen teljesítményt nyújtott a krízis kezelésében.

\section{Irodalomjegyzék}

Antal A. (2013) Politikai és jogi alkotmányosság Magyarországon. Politikatudományi Szemle, Vol. 22. No. 3. pp. 48-70.

Baudet, T. (2012) A határok jelentősége. Ford.: Lengyel Balikó Péter. Budapest, Századvég Kiadó

Bellamy, R. (2007) Political Constitutionalism: A Republican Defence of the Constitutionality of Democracy. Cambridge, Cambridge University Press

Chronowski N. (2015) Globális vagy lokális alkotmányosság? Jogelméleti Szemle, No. 4. pp. 19-31.

Coronavirus Will Change the World Permanently. Here's How. Elérhető: https://www.politico.com/news/magazine/2020/03/19/ coronavirus-effect-economy-life-society-analysis-covid-135579

Drinóczi T. (2015) Jurisztokrácia és az alkotmányoligarchia vagy a többszintű alkotmányosság és alapjogvédelem. Reflexiók Pokol Béla írására. Jogelméleti Szemle, No. 4. pp. 32-45.

Drinóczi, T. (2020) Hungarian Abuse of Constitutional Emergency Regimes - Also in the Light of the COVID-19 Crisis. MTA Law Working Papers, 13. sz.

Drinóczi, T. \& Bien-Kacala, A. (2019) Illiberal Constitutionalism: The Case of Hungary and Poland. German Law Journal, No. 20. 11401166.

Erdős Cs. (2016) Parlamenti autonómia. Aktustani elemzések az Országgyúlés jogállásáról és hatásköréről. Budapest, Gondolat Kiadó

Fukuyama, F. (2005) Államépités. Kormányzás és világrend a 21. században. Ford.: Kitta Gergely. Budapest, Századvég Kiadó

Fukuyama, F. (2020) The Pandemic and Political Order. It takes a State. Foreign Affairs, 2020. July/August. https://www.foreignaffairs.com/articles/world/2020-06-09/pandemic-and-politicalorder

Gardbaum, S. (2013) The New Commonwealth Model of Constitutionalism: Theory and Practice. Cambridge, Cambridge University Press

Halmai, G. (2020) How COVID-19 Unveils the True Autocrats: Viktor Orbán's Ermächtigungsgesetz. http://www.iconnectblog. com $/ 2020 / 04 /$ how-covid-19-unveils-the-true-autocrats-viktororbans-ermachtigungsgesetz/ 
Halmai, G. \& Scheppele, K. L. (2020) Don't Be Fooled by Autocrats!: Why Hungary's Emergency Violates Rule of Law. https://verfassungsblog.de/dont-be-fooled-by-autocrats/

Hirschl, R. (2004) Towards Juristocracy. The Origins and Consequences of the New Constitutionalism. Boston, Harvard University Press

Karsai, D. (2020) Let's not fool ourselves either!: Some remarks on Professor Halmai's and Professor Scheppele's blogpost. https:// verfassungsblog.de/lets-not-fool-ourselves-either/

Kovács Á. (2015): A passzív nem puha, avagy miért nem igazolható az Alkotmánybíróság gyakorlata a politikai konstitucionalizmus alapján? In: Gárdos-Orosz F. \& Szente Z. (szerk.) (2015) Jog és politika határán. Alkotmánybíráskodás Magyarországon 2010 után. Budapest, HVG-ORAC

Körösényi A. (2019) Max Weber és az Orbán-rezsim. Plebiszciter vezérdemokrácia Magyarországon. In: Körösényi A.: Manipuláció és demokrácia. Politikaelméleti tanulmányok. Budapest, Gondolat Kiadó

Mickletwait, J. \& Wooldridge, A. (2014) The Fouth Revolution. The Global Race to Reinvent the State. New York, The Penguin Press

Pócza K. (2012) Alkotmányozás Magyarországon és az Egyesült Királyságban. Kommentár, 5. sz. 35-50.

Poguntke, T. \& Webb, P. (eds) (2005) The Presidentialization of Politics - A Comparative Study of Modern Democracies. Oxford, Oxford University Press

Pokol B. (2017) A jurisztokratikus állam. Budapest, Dialóg Campus Kiadó
Pongrácz A. (2019) Nemzetállamok és új szabályozó hatalmak a globális erőtérben - avagy megszelídíthető-e a globalizáció? Budapest, Dialóg Campus

Sajó, A. (2018) The Constitution of Illiberal Democracy as a Theory About Society. Polish Sociological Review, Vol. 208. No. 4. pp. $395-412$.

Sajó, A. \& Uitz, R. (2017) The Constitution of Freedom. An Introduction to Legal Constitutionalism. Oxford, Oxford University Press

Sata-Ireneusz, R. \& Karolewski, P. (2019) Cesarian politics in Hungary and Poland. East European Politics, Vol. 36. No. 2 pp. 206-225. https://www.tandfonline.com/doi/full/10.1080/21599165.20 19.1703694

Stumpf I. (2014) Erôs állam - alkotmányos korlátok. Budapest, Századvég Kiadó

Szente Z. (2020) A 2020. március ll-én kihirdetett veszélyhelyzet alkotmányossági problémái. MTA Law Working Papers, 9. sz.

Tanács-Mandák F. (2014) A politika prezidencializációja - Magyarország, Olaszország. Pro Publico Bono: Magyar Közigazgatás, 4. sz. 110-119.

Tellér G. (1999) Hatalomgyakorlás az MSZP-SZDSZ koalíció idején. Budapest, Kairosz

Tóth R. \& Dobszay J. Orbán úgy adja vissza a felhatalmazást, hogy sok mindent megtart belóle. HVG, 2020. 05. 27. https://hvg. hu/360/20200527_A_szuksegtelen_plusz 